
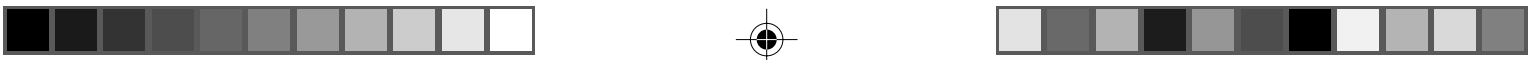

\title{
Position II
}

\section{KULTURMøDER, KULTUR OG RATIONALITET JAKOB EGHOLM FELDT}

Den nyligt afdøde amerikanske filosof Richard Rorty er næppe mest kendt som kulturfilosof, men ikke desto mindre vil jeg her forsøge at præsentere ham som sådan. Rortys filosofi fra gennembruddet i 1979 med Philosophy and the Mirror of Nature til det seneste værk Philosophy as Cultural Politics (2007) har vel tre hovedanliggender, som er: 1) Den måde, vi tænker om verden på, er ikke en refleksion af verden; 2) det er skift i vores måder at tale om verden på, som forandrer den; 3) det private og det offentlige behøver ikke reflektere hinanden. Man kan være narcissist privat, men pragmatiker offentligt. Hvor umiddelbart banale og gennemtærskede disse tanker lyder, så har Rorty gennem mere end 30 år ud fra disse forudsætninger formået at få vendt et utal af problemstillinger og dogmer i filosofien på måder, som har skabt voldsom debat.

Richard Rortys permanente arbejdsspørgsmål var: Hvordan ser tingene ud, hvis vi taler om dem på en anden måde? Dette spørgsmål ophæver jagten efter tingenes substans og retter i stedet blikket mod det, som ting bliver til og betyder, når vi taler om dem på bestemte måder. Filosofien, antropologien, litteraturvidenskaben osv. ophører således med at være analytisk og bliver i stedet for 'samtalende'. Rorty bruger 'analytisk' og 'samtalende' som et centralt filosofisk skel. I Rortys forstand betyder 'analytisk' at lede efter tingenes substans, jf. fx analytisk filosofi vs. kontinental filosofi. Kulturverdenens discipliner fletter tegn, spor, forskningshistorier, ideologier, utopier og personlige idiosynkrasier sammen til brug for den menneskelige samtale. Kulturerne, også de videnskabelige, er således i vores tjeneste, og derfor er det, vi bedriver som videnskabsmænd og -kvinder, kulturpolitik, mere end det er kulturanalyse.

Kulturmødet har efterhånden været tematiseret i mange år i kulturforskningen. Perspektivet går basalt set ud på at betragte kulturmødet som et møde mellem to eller flere forskellige ideer om, hvordan verden hænger sammen. Mødet kan naturligvis anskues ud fra en enorm variation af interesser, men præmissen er, at 

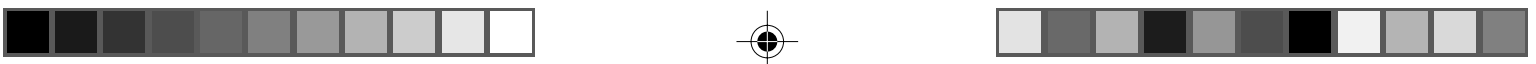

i mødet eller rettere konflikten mellem 'kulturer' kan vi forstå noget fundamentalt om vores kulturelle væren i verden. For kulturmødeforskningen er kulturbegrebet af afgørende betydning. Det må principielt være umuligt at definere noget som et kulturmøde, hvis man ikke først har klarlagt, hvad en kultur er. Perspektivet, man anlægger på kultur, på kulturs betydning og placering i identitetsforholdet individuelt og kollektivt, er afgørende for, hvordan man betragter kulturmødeproblematikker både forskningsmæssigt og praktisk.

I det følgende vil jeg præsentere Richard Rortys kulturbegreber, som afviger væsentligt fra kulturanalysens forskellige kulturbegreber, idet begreberne hos Rorty betragtes som et aspekt af selvforholdet, som man kan forholde sig politisk, refleksivt og terapeutisk til. Rorty er med sine begreber interesseret $i$, hvad vi vil med at forholde os til os selv på den måde, og han vil hele tiden overveje, om det ikke ville være bedre, hvis vi så på os selv på en anden måde. Kulturbegreberne kan derfor ikke stå alene. De må hænge sammen med måder at ræsonnere på, og derfor sammenholder Rorty sine kulturbegreber med rationalitetsbegreber, uden hvilke kulturbegreberne ville være meningsløse.

\section{Kultur og rationalitet}

Hos Rorty må man ikke tænke kulturbegreberne, før man har taget rationalitetsbegreberne med i betragtning. For måderne, hvorpå vi overvejer, hvorfor vi gør, som vi gør, udgør det ræsonnement, som gør vores kultur forståelig, selvfølgelig og naturlig. Selv det, vi ikke tænker men bare sanser som uacceptabelt, eller omvendt, familiært, er egentlig baseret på vores individuelle rationalitet og ikke på de sæt af vaner, normer og traditioner, som udgør vores kultur. Det er vores ræsonnement, som gør forhold i verden acceptable eller uacceptable, naturlige eller unaturlige, og som dermed skaber vores kulturer. Man kan indvende, at det bare er sådan, at den måde, vi tænker om ting på, er underlagt kulturen, og at Rorty derfor har en forkert rækkefølge i sin kulturtænkning. Rorty ville som liberal indvende, at så længe muligheden foreligger for at tænke anderledes om egen kultur, må man ansvarliggøre det enkelte individ, for deri ligger den individuelle frihed og den politiske mulighed for i fællesskab at gøre ting anderledes. Muligheden for at tænke over egen kultur og forholde sig til den pædagogisk og terapeutisk gør det mindre vigtigt, at vores måder at ræsonnere på er kulturelt prægede. Alene det at opfatte rationaliteten som kulturelt betinget er at forholde sig til et forhold, som man kunne forholde sig til på en anden måde.

Denne forholden-sig-til er Rortys selvrefleksive, selvterapeutiske udgangspunkt, der som et livsvilkår giver os muligheden for at gøre ting anderledes. Vilkåret går igennem kulturens forskellige repræsentationsniveauer fra kulturen til analysen 

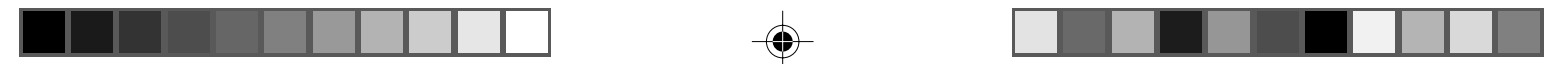

og redegørelsen for den. Vi kan således forholde os til vores egne ræsonnementer, vaner, normer og traditioner, og vi kan forholde os til vores forklaringer på, hvordan kulturer og kulturmøder virker i verden. Denne tankegang er udfordrende for kulturforskningen, fordi den gør konstateringen af, at vores tanker og forestillinger er underlagt en kulturel kontekst, relativt uinteressant. Dernæst ændrer den fokus fra kulturer som noget, der findes konkret i verden og kan mødes og strides med mennesker som repræsentanter, til måder at forholde sig til både sig selv og verden på, der bliver til på baggrund af individuelle og kollektive processer.

Med Rorty bliver spørgsmålene til kulturforhold diagnostiske og terapeutiske frem for redegørende og analyserende. En Rorty'sk diagnose af nutidens kulturforhold kunne lyde: Kultur, kulturmøder, kulturkonflikter er enormt eksponerede, iscenesatte, analyserede, definerede, fortalte osv. både historisk og i samtidsperspektiv; ergo har vi et problem med kultur. Terapi: Vi må se på, hvordan vi forholder os til kultur, andres, vores egen og vores iscenesættelse og analyser af den. Dernæst må vi vurdere, om det ikke ville være bedre at se på kultur på en anden måde. På den måde underminerer Rorty ideen om, at vi med vores videnskabelige artikler er ved at afdække kulturmødefænomenet som en ding an sich i verden, og viser os, at vi er i gang med at se på kulturen inden for vor samtids allerede herskende paradigme, nemlig som et fascinerende eller skræmmende problem. Rorty ville måske med en Nietzsche-parafrase sige, at kulturmødeproblematikken er meget tidssvarende og dermed ikke særligt refleksiv. Det tidssvarende er det forventelige, det uoriginale, som ikke peger mod noget nyt, men som befinder sig inden for det, jeg tidligere kaldte vor samtids allerede herskende paradigme.

Konkret opstiller Rorty tre forskellige kultur- og rationalitetsbegreber. Jeg vil i lyset af ovenstående redegøre for rationalitetsbegreberne først. Rorty beskriver rationalitet (1) som ,... evnen til at interagere med omgivelserne ved at justere sine reaktioner i forhold til omgivelsernes påvirkninger på komplekse og nuancerede måder" (Rorty 1998:186; min oversættelse, JF). Det er en evne, som alle levende væsener har, men mennesker er bedre til det end de fleste andre væsener. Det er en komplet værdifri evne, som ofte benævnes darwinistisk som 'evnen til overlevelse' eller sociologisk som 'instrumentel rationalitet'. Denne evne har intet med rigtigt og forkert eller 'det gode' at gøre. Rationalitet (2) derimod er en menneskelig kapacitet. Det er en tankegang, som får os til at beskrive os selv som anderledes end andre, og som tildeler os selv værdier. Rorty skriver: „Den er distinkt, fordi den sætter andre mål end simpel overlevelse; fx kan den fortælle dig, at det ville være bedre at være død end at gøre bestemte ting“ (ibid.; min oversættelse, JF).

Rationalitet (2) etablerer værdihierarkier og kan ikke reduceres til at dreje sig om konkrete mål og midler. Denne rationalitet handler om metafysik, dvs. det, 
der ligger ud over den konkrete verden og rationalitet (1). Rationalitet (3), mener Rorty, er mere eller mindre det samme som tolerance. Det handler om en evne til

... ikke at blive for forstyrret af forskelligheder fra en selv, ikke at reagere aggressivt på sådanne forskelligheder. Denne evne hænger sammen med villigheden til at ændre vaner - ikke for at få mere af det, man tidligere stræbte efter, men for at ændre sig selv og blive en anden slags person, som ønsker nogle andre ting end før (ibid.; min oversættelse, JF).

Denne rationalitetsform gør det muligt at leve sammen og løse problemer fredeligt. Den kan ses som den avancerede menneskelige overbygning på rationalitet (1) og kan fungere som en korrektion af denne. Den er nærmest metafysisk uden dog at være det i Rortys perspektiv, som helt afviser, at der findes noget meningsfuldt ud over, hvad mennesker finder på til forskellige tider.

Det er almindeligt at forbinde de tre rationaliteter til én, men det mener Rorty er en fundamental fejl. Det er således ikke sådan, at fordi mennesker har rationalitet (2), er vi bedre til rationalitet (1) end andre dyr. Det er heller ikke sådan, at mere rationalitet (1) fører til mere rationalitet (3). Når man lægger de tre rationaliteter sammen til én,

... begynder det måske at virke selvfølgeligt, at mennesker, som er gode til at udstyre sig selv med tekniske hjælpemidler til at tilfredsstille deres begær, også automatisk har det rette begær - begær i overensstemmelse med fornuften - og de forventes at udvise tolerance over for dem, som har alternative $\emptyset$ nsker, fordi de vil forstå, hvordan og hvorfor det uønskede begær blev til. Dette producerer ideen om, at det sted, hvor den meste teknologi kommer fra - Vesten - også er det sted, hvorfra man burde få sine moralske ideer og sociale dyder(Rorty 1998:187).

At det er forkert, kan man ifølge Rorty se, hvis man skiller rationalitet i tre forskellige typer.

Rorty opstiller herefter tre kulturbegreber. Kultur (1) er

... bare et sæt fælles handlingsnormer, som gør det muligt for medlemmer af et menneskeligt samfund at komme overens med hinanden og omgivelserne, så godt de nu kan (op.cit. 188; min oversættelse, JF).

Vi er alle medlemmer af mange sådanne kulturer, og denne type kultur er ikke kun noget mennesker har. Dyr i flokke har også adfærdskulturer, som hjælper dem med at være sammen. Det er en værdifri form for kultur, som ligner rationalitet (1). Kultur (2) derimod er en slags dyd. Det kan også benævnes 'højkultur', dvs. evnen til at tale sammen om kunst, kultur, politik osv. Det er noget, som man kan opnå gennem uddannelse, og som man kan associere til rationalitet (3), da det 

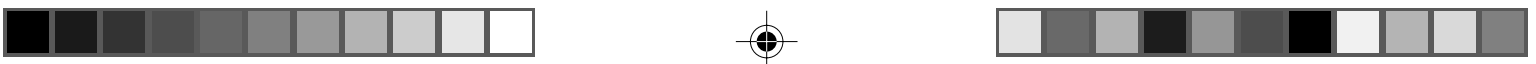

ofte er i intellektuelle, akademiske højkulturer, at man finder den største tolerance over for forskellighed, siger Rorty (ibid.).

Den sidste kulturform (3) er resultatet af rationalitet (2). Det er

... overvindelsen af det basale, irrationelle og dyriske ved hjælp af noget universelt menneskeligt, noget, som alle personer og kulturer er mere eller mindre i stand til at anerkende og respektere (ibid.; min oversættelse, JF).

Det er historiens fremadskriden mod realiseringen af det essentielt menneskelige, eller 'det gode samfund'. Kultur (3) er en meget almen kulturforståelse, som basalt set går ud på, at kultur er det, mennesker producerer, som dyr ikke gør, og som bevæger sig mod mere og mere avancerede former. I denne kulturforms perspektiv er historiens udviklingsmål kulturens totale dominans. Det er også i denne kulturforms perspektiv muligt at tale om grader af civilisation som en modsætning til dyriskhed eller primitivitet. I Rortys perspektiv er rationalitet (2) og kultur (3) 'farlige', fordi de reducerer henholdsvis rationalitet og kultur til en og samme ting, som tilmed er en menneskelig værdi og ikke bare tilpasningsmekanismer. Det er det rationalitets- og kulturbegreb, som Europa har koloniseret det meste af verden med, og som producerer kulturmøder og -konflikter.

\section{Afsluttende bemærkninger}

Richard Rortys kultur- og rationalitetsperspektiv er tydeligvis ikke rettet mod direkte anvendelse i antropologisk eller anden kulturforskning, men mod en filosofisk diskussion af, hvordan vi forholder os til kulturel forskellighed. Alligevel påpeger Rortys udredninger en række forhold, som er værd at overveje i kulturforskningen. Det er væsentligt, at Rorty gør opmærksom på tre overordnede kultur- og rationalitetsbegreber, som kan spille sammen på forskellige måder. Vi kan ikke definere kultur som ét 'noget' ifølge Rorty, men som tre forskellige typer af forhold: 1) en værdifri organisationsform; 2) en dyd; 3) en historisk proces. Sammenblandingen af de tre typer forhold medfører ofte en reduktion i både vores individuelle forholden os til kultur og i vores akademiske ditto, som leder til det, som Rorty definerer som kultur (3) og rationalitet (2). Filosofisk og politisk anbefaler Rorty helt at afskaffe talen om kultur (3) og rationalitet (2), som han mener er ubrugelige for vores evne til at leve med forskellighed. Det er umiddelbart irrelevant for den akademiske kulturanalyse og så alligevel ikke, fordi Rortys insisteren på vigtigheden af det, vi skaber, når vi skriver, kan hjælpe os med at forholde os til, hvad det er for kultur- og rationalitetsbegreber, vi selv formidler i vores artikler og bøger. 


\section{Litteratur}

Rorty, Richard

1979 Philosophy and the Mirror of Nature. Princeton: Princeton University Press.

1998 Truth and Progress. Cambridge: Cambridge University Press.

2007 Philosophy as Cultural Politics. Cambridge: Cambridge University Press. 